\title{
Front Matter: Volume 10593
}

, "Front Matter: Volume 10593," Proc. SPIE 10593, Bioinspiration, Biomimetics, and Bioreplication VIII, 1059301 (5 July 2018); doi: $10.1117 / 12.2326408$

Event: SPIE Smart Structures and Materials + Nondestructive Evaluation and SPIE. Health Monitoring, 2018, Denver, Colorado, United States 


\title{
PROCEEDINGS OF SPIE
}

\section{Bioinspiration, Biomimetics, and Bioreplication VIII}

\author{
Akhlesh Lakhtakia \\ Editor \\ 5-7 March 2018 \\ Denver, Colorado, United States
}

Sponsored by

SPIE

Cosponsored by

OZ Optics, Ltd. (United States)

Polytec, Inc. (United States)

Optical Society of Southern California (United States)

Cooperating Organizations

Jet Propulsion Laboratory (United States)

Colorado Photonics Industry Association (United States)

Published by

SPIE

Volume 10593 
The papers in this volume were part of the technical conference cited on the cover and title page. Papers were selected and subject to review by the editors and conference program committee. Some conference presentations may not be available for publication. Additional papers and presentation recordings may be available online in the SPIE Digital Library at SPIEDigitalLibrary.org.

The papers reflect the work and thoughts of the authors and are published herein as submitted. The publisher is not responsible for the validity of the information or for any outcomes resulting from reliance thereon.

Please use the following format to cite material from these proceedings:

Author(s), "Title of Paper," in Bioinspiration, Biomimetics, and Bioreplication VIII, edited by Akhlesh Lakhtakia, Proceedings of SPIE Vol. 10593 (SPIE, Bellingham, WA, 2018) Seven-digit Article CID Number.

ISSN: 0277-786X

ISSN: 1996-756X (electronic)

ISBN: 9781510616820

ISBN: 9781510616837 (electronic)

Published by

SPIE

P.O. Box 10, Bellingham, Washington 98227-0010 USA

Telephone +1 3606763290 (Pacific Time) · Fax +1 3606471445

SPIE.org

Copyright (C) 2018, Society of Photo-Optical Instrumentation Engineers.

Copying of material in this book for internal or personal use, or for the internal or personal use of specific clients, beyond the fair use provisions granted by the U.S. Copyright Law is authorized by SPIE subject to payment of copying fees. The Transactional Reporting Service base fee for this volume is $\$ 18.00$ per article (or portion thereof), which should be paid directly to the Copyright Clearance Center (CCC), 222 Rosewood Drive, Danvers, MA 01923. Payment may also be made electronically through CCC Online at copyright.com. Other copying for republication, resale, advertising or promotion, or any form of systematic or multiple reproduction of any material in this book is prohibited except with permission in writing from the publisher. The CCC fee code is 0277$786 \mathrm{X} / 18 / \$ 18.00$.

Printed in the United States of America.

Publication of record for individual papers is online in the SPIE Digital Library.

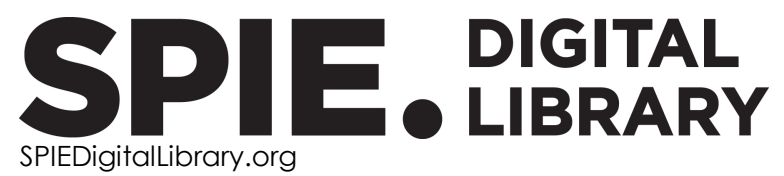

Paper Numbering: Proceedings of SPIE follow an e-First publication model. A unique citation identifier (CID) number is assigned to each article at the time of publication. Utilization of CIDs allows articles to be fully citable as soon as they are published online, and connects the same identifier to all online and print versions of the publication. SPIE uses a seven-digit CID article numbering system structured as follows:

- The first five digits correspond to the SPIE volume number.

- The last two digits indicate publication order within the volume using a Base 36 numbering system employing both numerals and letters. These two-number sets start with 00, 01, 02, 03, 04, 05, 06, 07, 08, 09, OA, OB ... 0Z, followed by 10-1Z, 20-2Z, etc. The CID Number appears on each page of the manuscript. 


\section{Contents}

$\begin{array}{ll}\text { ix } & \text { Authors } \\ \text { xi } & \text { Conference Committee }\end{array}$

INAUGURAL SESSION

1059302 Paradigms for biologically inspired design (Keynote Paper) [10593-1]

FLIGHT I

1059303 Bioinspired pitch control using a piezoelectric horizontal tail for rudderless UAVs (Best Student Paper Award) [10593-2]

1059304 Technological demonstration of an adaptive aileron system [10593-3]

1059305 Optimisation design process of a morphing winglet [10593-4]

MATERIAL STRUCTURES I

1059307 Toward multicontrollable metasurfaces [10593-7]

BIO-OPTICS

10593 OB Bioinspired invertebrate pest detection on standing crops [10593-9]

10593 OC Replication of large-area Morpho-color material using flexible mold [10593-10]

10593 OD A bioinspired broadband reflector in the VIS-NIR wavelength range [10593-11]

ENERGY

$10593 \mathrm{OF}$ Photosynthesis as a guide to small scale production of energy from $\mathrm{CO}_{2}$ [10593-12] 
10593 OG Bioinspired pseudo-ductile composite laminates with hierarchical energy absorption mechanism [10593-13]

$10593 \mathrm{OH} \quad$ Investigation of leaf shape and edge design for faster evaporation in biomimetic heat dissipation systems [10593-14]

\section{ROBOTICS}

$10593 \mathrm{Ol}$ Interactive experiments in a robotics-based platform to simulate zebrafish response to a predator [10593-15]

10593 OJ Performance analysis of resilient bioinspired structural systems (Best Student Paper Award and SPIE Best Student Paper Award) [10593-16]

\section{ADHESION}

$10593 \mathrm{OM}$ Observation of micro-topography of newt toe pads and investigating on wet adhesive properties of microstructured surface of PDMS [10593-19]

10593 ON A wall-climbing robot using gecko-inspired dry adhesives and underactuated modular connecting mechanism [10593-20]

$1059300 \quad$ Adhesive beads [10593-22]

\section{FLIGHT II}

10593 OU Robustness strategies in bio-inspired flight systems: morphology, dynamics and flight control (Invited Paper) [10593-27]

10593 OV Transition flight control simulations of bioinspired FWMAV with extended unsteady vortex-lattice method [10593-28]

10593 OW Comparison of bio-inspired flapping foil propulsion systems with rotary propulsion [10593-29]

\section{SOFT MATTER}

10593 OY Bio-inspired passive variable recruitment of fluidic artificial muscles [10593-31]

$10593 \mathrm{OZ} \quad$ Actuation of soft materials through ultrasonic atomization [10593-32]

$1059310 \quad$ Characterizing nitinol wire bond strength in silicone for artificial skin muscles [10593-33] 
MATERIAL STRUCTURES II

1059313 Versatile strategies for the development of wood-based functional materials (Invited Paper) [10593-36]

\section{POSTER SESSION}

$1059316 \quad$ Using the chemistry of seawater to make functional smart ports [10593-39]

1059317 In-situ coating for $\mathrm{CO}_{2}$ conversion at tail pipes and in ambient air in which oxygen is given off: it makes coated concrete stronger [10593-40]

1059318 Development of a PVDF based artificial basilar membrane [10593-41] 
Proc. of SPIE Vol. 10593 1059301-6

Downloaded From: https://www.spiedigitallibrary.org/conference-proceedings-of-spie on 26 Apr 2023 Terms of Use: https://www.spiedigitallibrary.org/terms-of-use 


\section{Authors}

Numbers in the index correspond to the last two digits of the seven-digit citation identifier (CID) article numbering system used in Proceedings of SPIE. The first five digits reflect the volume number. Base 36 numbering is employed for the last two digits and indicates the order of articles within the volume. Numbers start with 00, 01, 02, 03, 04, 05, 06, 07, 08, 09, OA, OB...0Z, followed by 10-12, 20-2Z, etc.

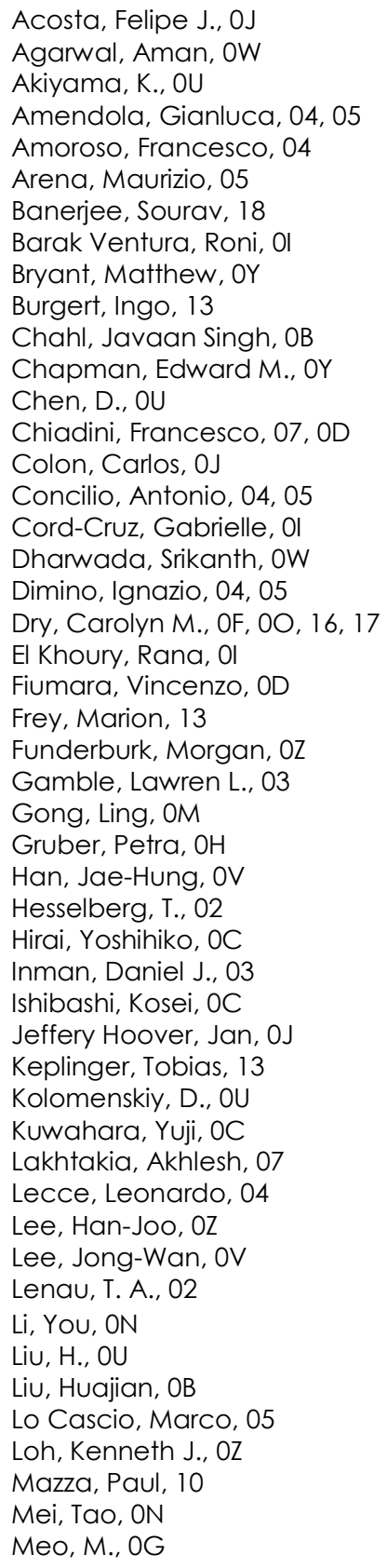

Metze, A.-L., 02

Milazzo, Alberto, 05

Milenski, Michael, 10

Nakata, T., OU

Nguyen, Anh Tuan, OV

Noda, R., OU

Ohga, Junpei, OC

Patel, Reena R., 0J

Pecora, Rosario, 04

Perkins, Edward J., OJ

Peters, John F., OJ

Pinto, F., OG

Porfiri, Maurizio, 0

Rajagopal, Prabhu, OW

Riveros, Guillermo A., 0J

Rizzo, F., OG

Ruberto, Tommaso, 이

Rupp, Ariana I. K. S., $\mathrm{OH}$

Saadatzi, Mohammad Nasser, 18

Saadatzi, Mohammadsadegh, 18

Saito, Akira, OC

Santamaria, Anthony D., 10

Scaglione, Antonio, OD

Shin, Moochul, 10

Tavaf, Vahid, 18

Thompson, David S., OJ

Ueyama, K., OU

Wang, Rongchuan, ON

Wang, Xiaojie, OM, ON

Wu, Xuan, OM, ON

Yu, Haiwu, OM 
Proc. of SPIE Vol. $105931059301-8$

Downloaded From: https://www.spiedigitallibrary.org/conference-proceedings-of-spie on 26 Apr 2023 Terms of Use: https://www.spiedigitallibrary.org/terms-of-use 


\title{
Conference Committee
}

\author{
Symposium Chairs
}

Tribikram Kundu, The University of Arizona (United States)

Gregory W. Reich, Air Force Research Laboratory (United States)

Symposium Co-chairs

Zoubeida Ounaies, The Pennsylvania State University (United States) Hoon Sohn, KAIST (Korea, Republic of)

Conference Chair

Akhlesh Lakhtakia, The Pennsylvania State University (United States)

Conference Co-chairs

Raúl J. Martín-Palma, Universidad Autónoma de Madrid (Spain)

Mato Knez, CIC nanoGUNE Consolider (Spain)

Conference Program Committee

Javaan S. Chahl, University of South Australia (Australia)

Vincenzo Fiumara, Università degli Studi della Basilicata (Italy)

Olaf Karthaus, Chitose Institute of Science and Technology (Japan)

Mathias Kolle, Massachusetts Institute of Technology (United States)

Kostya Kornev, Clemson University (United States)

Bert Müller, Basel University Hospital (Switzerland)

Maurizio Porfiri, NYU Tandon School of Engineering (United States)

Akira Saito, Osaka University (Japan)

Kathleen Stebe, University of Pennsylvania (United States)

Cordt Zollfrank, Technische Universität München (Germany)

Session Chairs

1 Inaugural Session

Akhlesh Lakhtakia, The Pennsylvania State University (United States)

2 Flight I

Vincenzo Fiumara, Università degli Studi della Basilicata (Italy)

3 Material Structures I

Mato Knez, CIC nanoGUNE Consolider (Spain)

Akhlesh Lakhtakia, The Pennsylvania State University (United States) 
Bio-Optics

Petra Gruber, University of Akron (United States)

5 Energy

Vincenzo Fiumara, Università degli Studi della Basilicata (Italy)

6 Robotics

Torben A. Lenau, Technical University of Denmark (Denmark)

7 Adhesion

Andreas Walther, Albert-Ludwigs-Universität Freiburg (Germany)

8 Particulate Matter

Mato Knez, CIC nanoGUNE Consolider (Spain)

Akhlesh Lakhtakia, The Pennsylvania State University (United States)

9 Flight II

Torben A. Lenau, Technical University of Denmark (Denmark)

10 Soft Matter

Tobias Keplinger, ETH Zürich (Switzerland)

11 Material Structures II

Kwang Jin Kim, University of Nevada, Las Vegas (United States)

12 Tutorial Lecture

Akhlesh Lakhtakia, The Pennsylvania State University (United States) 